Original Research

\title{
Anaerobic Co-Digestion of Waste Wafers from Confectionery Production with Sewage Sludge
}

\author{
Agnieszka A. Pilarska* \\ Poznań University of Life Sciences, Institute of Food Technology of Plant Origin, \\ Wojska Polskiego 28, PL-60637 Poznań, Poland
}

Received: 10 March 2017

Accepted: 3 May 2017

\begin{abstract}
Food waste $(\mathrm{FW})$ is generated in high volumes and is a serious threat to the environment if utilized improperly or left without control. Conventional methods of FW disposal include combustion, landfilling, aerobic composting, partial recycling, and other ones. Anaerobic digestion (AD) is the most environmentally friendly of all the methods as it is beneficial to the populace, and food waste is a suitable material for biogas production.

Confectionery waste has rarely been utilized by anaerobic digestion (AD) so far. In this paper, the use of waste wafers (WF) in co-digestion with sewage sludge (SS) is proposed for the first time. Annual volumes of production of WW and SS are expressed in hundreds and thousands of tons, respectively. The materials are generated in high amounts and on an ongoing basis, which is a very important factor regarding potential biogas plant investment projects. The objective of this paper was to analyze the AD process of the test substrates in terms of process stability and biogas capacity. The studies have shown that both the waste wafers as the individual material and with sewage sludge (as the co-substrate) are suitable feedstocks for biogas production. The experiments were carried out for the individual material and for a system with a cosubstrate in the form of raw sewage sludge (SS). In both cases, a digested sewage sludge was used as the inoculum. The studies were performed in a laboratory scale using anaerobic batch reactors under controlled (mesophilic) temperature and $\mathrm{pH}$ conditions. The highest yields of biogas and methane were obtained for waste wafers (980.1 $\mathrm{m}^{3} \mathrm{Mg} \mathrm{VS}^{-1}$ and $492.6 \mathrm{~m}^{3} \mathrm{Mg} \mathrm{VS}^{-1}$, respectively) and the lowest for raw sewage sludge (349.1 $\mathrm{m}^{3} \mathrm{Mg}^{-1} \mathrm{VS}$ and $177.9 \mathrm{~m}^{3} \mathrm{Mg}^{-1} \mathrm{VS}$, respectively). After mixed the wafers with the sewage sludge, the material (WF_SS) produced less biogas $\left(667.9 \mathrm{~m}^{3} \mathrm{Mg}^{-1} \mathrm{VS}\right)$, including methane (387.5 $\mathrm{m}^{3}$ $\mathrm{Mg} \mathrm{VS}^{-1}$ ), than for the wafers (WF). The differences in biogas production for the samples were primarily connected with the substrates' composition, including with the content of readily degradable organic compounds and $\mathrm{C} / \mathrm{N}$ ratio. The combination of waste wafers with raw sewage sludge has appeared to be beneficial, as evidenced by the results of microbiological and biochemical analyses. The sample WF_SS was
\end{abstract}

*e-mail: pilarska@up.poznan.pl 
rich in microorganisms with high metabolic activity, which resulted in the production of biogas with high methane content (58\%).

Keywords: waste wafers, sewage sludge, anaerobic co-digestion, biogas yield, microbiological analysis

\section{Introduction}

Anaerobic digestion (AD) has many environmental benefits, including the production of a renewable energy carrier, the possibility of nutrient recycling, and reduction of waste volumes [1]. The AD process is composed of biochemical reactions, catalyzed by numerous groups of microorganisms which cooperate with each other, thus each contributing to the production of biogas [2]. The bacteria that take part in the $\mathrm{AD}$ process are classified as obligatory and facultative anaerobes. The initial steps of the anaerobic digestion process, that is, hydrolysis of complex compounds and acidogenesis, are mainly effected by saprophytes of the species: Pseudomonas, Bifidobacterium, Clostridium, Bacteroides, and, to a lesser degree, by Streptococcus and Enterobacterium. Organic acids, alcohols, and ketones, which are formed in the process of acidogenesis in the presence of the bacterial species Synthrophobacter and Synthrophomonas, are further processed to acetate, carbon dioxide, and hydrogen in the process of acetogenesis [3]. The final step of anaerobic digestion consists in the conversion of acetate to $\mathrm{CH}_{4}, \mathrm{H}_{2} \mathrm{O}$, and $\mathrm{H}_{2}$ in the presence of archaea, such as the species Methylomirabilis, Methanosarcina, Methanobacterium, and Methanococcus [4].

Waste arising in the food industry is one of the most readily biodegradable types of organic material that can easily be digested in anaerobic conditions to produce biogas $[2,5]$. According to literature reports, the $\mathrm{AD}$ process is most typically applied to food waste from restaurants [6-7], either individually or after mixing it with other substrates. Moreover, experiments are carried out with food waste arising in the food processing industry such as sugar beet pulp [8], molasses [9], cheese whey [10], fat [11], coffee waste [12], fruit and vegetable waste [13], and dumpling waste [14]. Those with the use of waste arising in confectionery production are carried only very rarely, even though the material - which is usually highly concentrated and rich in carbohydrates - is a promising substrate for the production of biogas, including methane. This subject was reported in only two out of a number of papers on anaerobic digestion [15-16].

The confectionery industry generates both solid and, less often, liquid wastes. One of the most common types of solid waste is defective confections, including wafers. Imperfectly shaped, stuck together, broken, or only packed defectively or labeled incorrectly, defective confections are produced in quantities that can reach up to $10 \%$ of total confectionery production. Other kinds of waste being produced in similar quantities are dough, chocolate mass, fatty flavor fillings, starch from jelly production, etc. [16]. Liquid waste is usually a post-process water. The weekly output production volume of waste in a typical production facility, also in Poland, is assessed in tons [16]. The confectionery industry mostly disposes of the solid waste products through combustion and the process water through a municipal wastewater treatment plant (WWTP).

More and more frequently, has it been proposed to use confectionery production waste as a starting material for making animal fodders. However, this requires a very good knowledge of the material's origin and chemical composition as well as its supplementation and hygienization. The costs of preprocessing and transport are to be taken into account as well. Anaerobic digestion is the optimum method for the disposal of confectionary waste: it is both cost-effective and environmentally friendly. The method enables manufacturers to obtain what is called the "green label," confirming their low environmental impact. The major advantage of the method is that it helps overcome dependence on fossil fuels by using the confectionery waste for making biogas.

Sewage sludge is one more example of organic waste, used as a substrate for making biogas $[7,8,10-15,17-$ 20]. Among biological methods, which include also aerobic digestion and composting, anaerobic digestion is perceived to be the most environmentally friendly and cost-effective method for neutralization and disposal of sewage sludge [1]. On the other hand, the material cannot be regarded as an efficient source of biogas. Its content of solids is usually low; therefore, production of biogas solely from sewage sludge is not profitable. Moreover, when applying $\mathrm{AD}$ to raw sewage sludge, it is necessary to take into account the possible microbiological disturbances in the process, which are mainly due to the toxic effect of heavy metals and chemical compounds that are present in the sewage sludge [21-22]. Hence, the anaerobic codigestion of a combination of sewage sludge and other organic waste, including from confectionery production, may be of benefit to both partners. It is a feasible option which, on the one hand, enables biogas production with high yields by improving the content of carbon and the balance of mineral components and, on the other, helps dilute toxic substances and intensifies the degree of substrate digestion, but also provides a stable process [23]. It is worth adding that the volume of sewage sludge per annum can be tens of tons per year, depending on the infrastructure of the given waste treatment plant and on applicable environmental laws. In turn, the confectionery waste volume generated per year can be as large as hundreds of tons, depending on factory capacity. In the case of ongoing production of both the sewage sludge and confectionery waste, both kinds of material are available for utilization in anaerobic co-digestion to make methane; also, this can help make decisions on building biogas plants based on the two substrates. 
Table 1. Physicochemical properties of substrates and inoculum used in the experiment.

\begin{tabular}{|c|c|c|c|c|}
\hline Indicator & Unit & Waste wafers (WF) & Sewage sludge (SS) & Inoculum \\
\hline $\mathrm{pH}$ & - & 7.00 & 6.02 & 7.19 \\
\hline Conductivity & $\mathrm{mS} \mathrm{cm}^{-1}$ & 1.95 & 3.53 & 30.04 \\
\hline TS wt $\%$ & wt $\%$ & 94.15 & 5.40 & 2.70 \\
\hline VS & wt $\%_{\mathrm{TS}}$ & 98.71 & 91.79 & 67.64 \\
\hline $\mathrm{C}: \mathrm{N}$ ratio & - & 42.46 & 7.68 & 3.08 \\
\hline $\mathrm{C}$ & wt $\%_{\text {TS }}$ & 41.61 & 38.40 & 27.70 \\
\hline $\mathrm{N}$ & wt $\%_{\text {TS }}$ & 0.98 & 5.00 & 8.98 \\
\hline $\mathrm{N}-\mathrm{NH}_{4}$ & $\mathrm{wt} \%_{\mathrm{TS}}$ & 0.33 & 0.35 & 3.48 \\
\hline$P$ & $\mathrm{mg} \mathrm{kg}^{-1}$ & 152 & 1,180 & 2,560 \\
\hline COD & $\mathrm{mg} \mathrm{L}^{-1}$ & 1,380 & 3,050 & 1,590 \\
\hline VFA & $\mathrm{mg} \mathrm{L}^{-1}$ & - & 3,500 & 220 \\
\hline \multicolumn{5}{|c|}{ Light metal ions } \\
\hline $\mathrm{K}$ & \multirow{4}{*}{$\mathrm{mg} \mathrm{kg}^{-1}$} & 39 & 2,600 & 3,400 \\
\hline $\mathrm{Na}$ & & 168 & 3,800 & 6,200 \\
\hline $\mathrm{Mg}$ & & 32 & 19 & 33 \\
\hline $\mathrm{Ca}$ & & 166 & 37 & 52 \\
\hline \multicolumn{5}{|c|}{ Heavy metals } \\
\hline $\mathrm{Zn}$ & \multirow{6}{*}{$\mathrm{mg} \mathrm{kg}^{-1}$} & $\mathrm{NA}^{\mathrm{a}}$ & 37.5 & 37.8 \\
\hline $\mathrm{Cu}$ & & NA & 14.4 & 12.6 \\
\hline $\mathrm{Cr}$ & & NA & 6.9 & 5.7 \\
\hline $\mathrm{Ni}$ & & NA & 5.6 & 3.1 \\
\hline $\mathrm{Pb}$ & & NA & 3.5 & 2.51 \\
\hline $\mathrm{Cd}$ & & NA & 0.054 & 0.041 \\
\hline
\end{tabular}

${ }^{\mathrm{a}} \mathrm{NA}=$ not analyzed

The main objective of this paper is to assess the stability and yield of biogas production by $\mathrm{AD}$ of waste wafers both as an individual material and after combining it with raw sewage sludge. The digested sewage sludge was used as the inoculum. The experiments were carried out in a laboratory scale in a periodic manner at controlled (mesophilic) temperatures and $\mathrm{pH}$ conditions. Changes in the number of the anaerobic bacteria and the level of dehydrogenase activity were also monitored.

\section{Material and Methods}

Substrates and Inoculum

A substrate in the form of waste wafers with filling were obtained from a manufacturer in Poznań. The sewage sludge (raw and digested) was obtained from the municipal waste treatment plant in Poznań, operated by Aquanet S.A. The digested sewage sludge was used in the experiment as the inoculum and the raw sewage sludge was used as the co-substrate. The physico-chemical properties of the materials used in the experiments are shown in Table 1.

\section{Experimental Procedure}

In the first phase of the experiment, digestion mixtures were prepared in the form of three starting materials: WF/inoculum, SS/inoculum, and WF_SS/inoculum (Table 2). The compositions of the mixtures were determined in accordance with the standard providing guidelines for performing the process of digestion of organic materials [24]. Based on the guidelines, the present authors attempted to keep the total solids content (TS) of the batch less than $10 \%$ to guarantee adequate mass transfers and the content of volatile solids (VS) in the batch from inoculum - between 1.5 and $2 \%$. The $\mathrm{pH}$ of the mixtures before digestion was in the range 6.8-7.5. 
Table 2. Composition and selected properties of the digestion mixtures substrate/inoculum.

\begin{tabular}{|c|c|c|c|c|c|}
\hline Sample & $\begin{array}{c}\text { Substrate } \\
(\mathrm{g})\end{array}$ & $\begin{array}{c}\text { Inoculum } \\
(\mathrm{g})\end{array}$ & $\mathrm{pH}$ & $\begin{array}{c}\text { Conductivity } \\
\left(\mathrm{mS} \mathrm{cm}^{-1}\right)\end{array}$ & $\begin{array}{c}\text { TS } \\
(\%)\end{array}$ \\
\hline WF/inoculum & 10 & 1190 & 7.20 & 7.93 & 3.18 \\
\hline SS/inoculum & 180 & 1020 & 6.95 & 30.70 & 3.10 \\
\hline WF_SS/inoculum & $\begin{array}{c}7+103 \\
(\mathrm{WF}+\mathrm{SS})\end{array}$ & 1090 & 7.02 & 32.20 & 3.47 \\
\hline
\end{tabular}

Biogas production rates as well as biogas and methane yield analyses were carried out in accordance with the German standard [25]. The anaerobic digestion process was performed using a multichamber biofermenter (Fig. 1). Daily changes in the $\mathrm{pH}$ values of each test sample were monitored during the experiment (Fig. 2).

Twelve $1.4 \mathrm{~L}$ biofermenters were used in these tests. Each biofermenter was filled with $1 \mathrm{~L}$ of a starting material composed of suitable substrate mixtures. The samples composed of substrate/inoculum and the inoculum alone (also referred to as control) were digested in three repetitions. The material was stirred once in $24 \mathrm{hrs}$ to prevent any uncontrollable decay of organic matter. The absence of oxygen in the digestion chamber plus the addition of the inoculum created the perfect conditions for methane generation. The biofermenters were equipped with a water jacket (4) connected to a heater (1). This enabled the control of temperature and performance of the process in a desirable temperature range. The study was carried out in mesophilic conditions $\left(38-40^{\circ} \mathrm{C}\right)$ that correspond to typical conditions actually prevailing in most biogas plants. The biogas produced was transported via a tube (7) into tanks (8) filled with a neutral liquid. In accordance with the standard [25], the experiment was continued for each sample until daily biogas production was below $1 \%$ of its total generated amount.

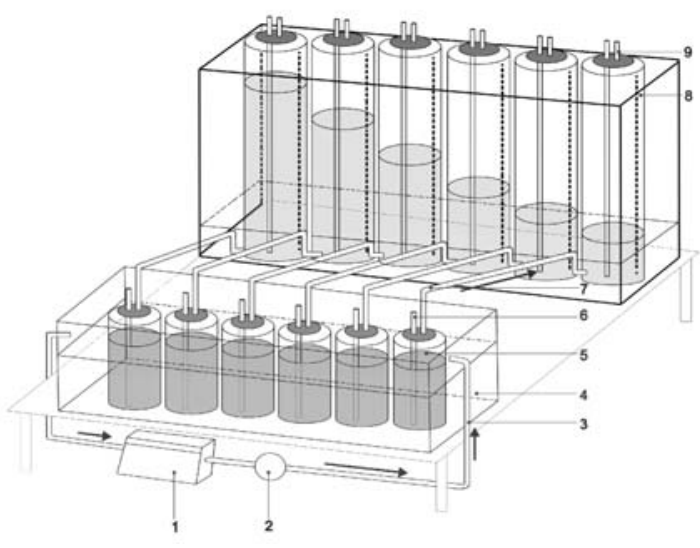

Fig. 1. Biofermenter for biogas production tests (6-chamber section): 1) water heater with temperature adjustment, 2) water pump, 3) insulated tubes for liquid heating medium, 4) water jacket $\left.\left(39^{\circ} \mathrm{C}\right), 5\right)$ biofermenter $\left.\left(1.4 \mathrm{dm}^{3}\right), 6\right)$ slurry-sample drawing tube, 7) tube for transporting the biogas generated, 8) graduated tank for biogas, and 9) gas sampling valve [26].

\section{Analytical Methods}

The parameters of the substrate and the inoculum were analyzed in accordance with the suitable standards/ procedures (Table 3). The generated gas volumes were measured at 24-hour intervals. A qualitative analysis of the gas was carried out for the gas volumes of $1 \mathrm{~L}$ or higher, initially once a day, then - as lower volumes were generated - every third day. The concentrations of methane, carbon dioxide, hydrogen sulfide, ammonia, and oxygen were measured using the gas analyzer Geotech GA5000.

The quantitative and qualitative analyses of the gas obtained were followed by the assessment of the biogas yield per unit $\left(\mathrm{m}^{3} \mathrm{Mg}^{-1} \mathrm{VS}\right)$ of organic dry matter based on test results. The biogas yield for the substrates was calculated by subtracting the gas volume generated for the inoculum [26]. For the batches in the reactors filled with the substrate mixtures, the gas generated from inoculum was calculated from the following equation:

$$
V_{I S(\text { corr })}=\frac{\sum V_{I S} m_{I S}}{m_{M}}
$$

...where $\mathrm{V}_{\text {IS(corr.) }}$ is gas volume released from the inoculum $\left(\mathrm{ml}_{\mathrm{N}}\right), \Sigma \mathrm{V}_{\mathrm{IS}}$ is the total gas volumes in the test performed on inoculum for the given test duration $\left(\mathrm{ml}_{\mathrm{N}}\right), \mathrm{m}_{\mathrm{IS}}$ is mass of the inoculum used for the mixture $(\mathrm{g})$, and $\mathrm{m}_{\mathrm{M}}$ is mass of the inoculum used in the control test $(\mathrm{g})$.

The specific digestion gas production, $\mathrm{V}_{\mathrm{S}}$, from the substrate vs. test duration is calculated from reading to reading in accordance with the equation:

$$
V_{S}=\frac{\Sigma V_{n} 10^{4}}{m w_{T} w_{V}}
$$

... where $\mathrm{V}_{\mathrm{S}}$ is specific digestion gas production relative to the ignition loss mass during the test period $\left(\mathrm{L}_{\mathrm{N}} \mathrm{kgGV}^{-1}\right)$, $\Sigma \mathrm{V}_{\mathrm{n}}$ is net gas volume of the substrate for the given test time $\left(\mathrm{mL}_{\mathrm{N}}\right), \mathrm{m}$ is mass of the weighed-in substrate $(\mathrm{g}), \mathrm{w}_{\mathrm{T}}$ is dry residue of the sample (\%), and $\mathrm{w}_{\mathrm{V}}$ is loss on ignition $(\mathrm{GV})$ of dry mass of the sample (\%).

Microbiological analyses at the following seven consecutive time points of the experiment's duration (I - commencing the experiment, II - Day 3, III - Day 
Table 3. Methods and standards.

\begin{tabular}{|c|c|}
\hline Parameter & Method and standard \\
\hline $\mathrm{pH}$ & Potentiometric analysis, PN-EN 12176:2004, EN 15933:2012 \\
\hline Total solids & $\begin{array}{c}\left.\text { Gravimetric analysis (105 }{ }^{\circ} \mathrm{C}\right), \text { PN-EN 12880:2004, } \\
\text { EN 15934:2012 }\end{array}$ \\
\hline Volatile solids & Gravimetric analysis (550 ${ }^{\circ}$ C), PN-EN 12879:2004, \\
\hline EN 15935:2012
\end{tabular}

7, IV - Day 10, V - Day 13, VI - Day 17, and VII Day 21 of digestion) were carried out by the Koch plate method: the number of colony forming units (cfu) of the heterotrophic true bacteria was found using the selective medium agar standard from Merck (Merck 2004). The bacteria were counted after incubating them for $24 \mathrm{hrs}$ at $35^{\circ} \mathrm{C}$. The anaerobic conditions in which Petri dishes were incubated were created by means of the Anaerocult bags from Merck with the addition of an oxygen absorbant.

Dehydrogenase activities in the digest test samples were determined spectrophotometrically as part of enzymatic analyses. The level of enzymatic activity was found using 1\% triphenyltetrazolium chloride (TTC) as substrate after $24-\mathrm{hr}$ incubation at a temperature of $30^{\circ} \mathrm{C}$ and a wavelength of $485 \mathrm{~nm}$. The enzymatic activity was expressed in $\mu \mathrm{mol}$ TPF $\cdot \mathrm{g}^{-1}$ of dry matter of the digest $\cdot 24 \mathrm{~h}^{-1}$ (TPF - triphenylformazan) [27].

Statistical processing of the results - including the calculation of straight-line regression indicating the type of dependence between the bacterial count and dehydrogenase activity as well as determining the least significant difference $\left(\mathrm{LSD}_{0,01}, \mathrm{LSD}_{0,05}\right)$ in the number of true bacteria and in the level of enzymatic activity - was carried out using Statistica 12.0 software (StatSoft Inc. 2012).

\section{Results and Discussion}

\section{Substrate Characterization}

The waste wafers with filling (WF) that were used in this paper as the base substrate are characterized by high total solids (TS), volatile solids (VS), and C/N ratio
(Table 1). This confirms that the material is perfect for biogas production. The values of the other parameters, including the content of ammonium nitrogen and light metal ions, exclude the possibility of process inhibition, according to literature data [28].

The inoculum (digested sludge) and raw sludge, as used in the experiment, are characterized by low content of TS compared with waste wafers (Table 1). The values of $\mathrm{C} / \mathrm{N}$ ratio both for the inoculum and for the raw sewage sludge (SS) are also low. Interestingly enough, the inoculum is characterized by a rather high value of conductivity, which confirms the presence of mineral components, potentially favoring the development and metabolism of anaerobic bacteria $[26,29]$. The results obtained by the present authors indicate that the levels of potassium, magnesium, sodium, and calcium in the inoculum are higher in comparison with the raw SS. In turn, the chemical oxygen demand (COD) was $1,590 \mathrm{mg} \mathrm{dm}^{-3}$ for the digested sludge, and nearly twice as high $\left(3,050 \mathrm{mg} \mathrm{L}^{-1}\right)$ for the raw sewage sludge; this is comparable with literature reports [26, 3031]. The data indicate that reduction in the process of $A D$ took place for ionic organic and inorganic compounds such as iron(II) sulfides - potential contaminants of the sewage sludge.

Table 1 also shows the content of heavy metals in the sewage sludge. Numerous reports indicate that certain concentrations of heavy metals at specific process conditions tend to inhibit anaerobic digestion [21] because the heavy metals combine with proteins in microorganisms and inactivate enzymes. However, not all bacteria are equally sensitive to heavy metals since various immunity mechanisms have been developed. For instance, acidogenic species are less sensitive to the effect of heavy metals in comparison with methanogens [21,26]. 


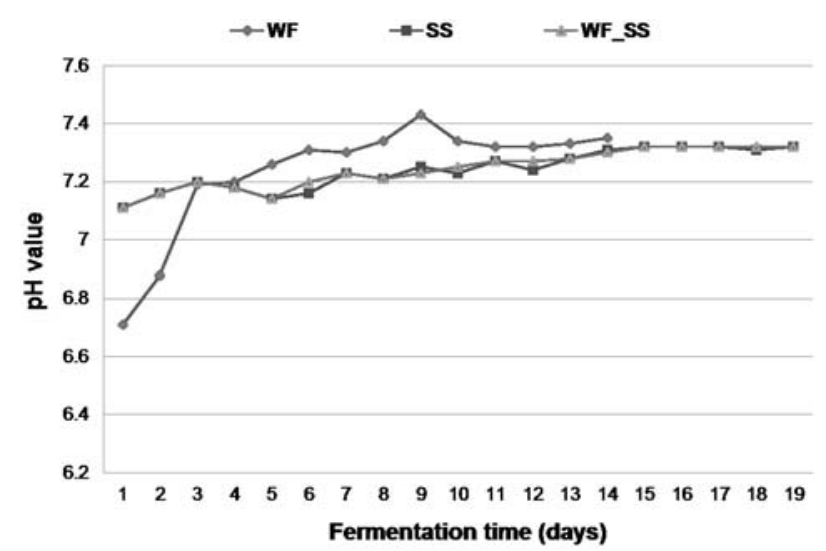

Fig. 2. $\mathrm{pH}$ variation for digested substrates: waste wafers (WF), mixtures waste wafers/sewage sludge (WF_SS), and sewage sludge (SS).

According to the listed concentrations at which inhibition starts, as proposed by Deublein and Steinhauser [32], every concentration of heavy metals in sewage sludge may have an inhibitory effect on methane production.

\section{Cumulative Biogas Production}

Digestion of each of the test samples took place in a stable manner, as indicated by the results of $\mathrm{pH}$ measurements (Fig. 2). The $\mathrm{pH}$ values varied between 6.70 and 7.41, which is within the range of tolerance for methanogens. The duration of the digestion process was the shortest (17 days) for the wafers (because of their high content of readily biodegradable carbohydrates) and somewhat longer (20 days) for sewage sludge alone and for wafers combined with sewage sludge.

Figures 3(a,c) show the daily yields of biogas and methane for WF, SS, and WF_SS, respectively. The biogas production process shows the highest intensity for the wafers (Fig. 3a). For the initial days, the content of methane in biogas is much lower than "other gases." Starting from Day 4, the ratio varies and methane starts to dominate in the biogas. A similar tendency in biogas composition was observed for the other two samples: SS and WF_SS (Figs $3(\mathrm{~b}, \mathrm{c})$; however, biogas volume, in accordance with the values in the Y-axis, is lower in both cases compared with the wafers alone).

According to the data in Table 4, the highest cumulative biogas and methane yields were obtained for wafers (980.1 $\mathrm{m}^{3} \mathrm{Mg}^{-1} \mathrm{VS}$ and $492.6 \mathrm{~m}^{3} \mathrm{Mg}^{-1} \mathrm{VS}$, respectively), and the lowest were obtained for raw sewage sludge (349.1 $\mathrm{m}^{3} \mathrm{Mg}^{-1} \mathrm{VS}$ and $177.9 \mathrm{~m}^{3} \mathrm{Mg}^{-1} \mathrm{VS}$, respectively). Comparable relationships were recorded for yields in terms of total solids of the substrates. The biogas produced from SS had a higher methane content $(51.0 \%)$ compared with that obtained from WF $(50.3 \%)$. The highest content of methane in the biogas was obtained for the WF_SS test sample $(58.0 \%)$. The result proves that there is a synergic effect between the combined materials. Wafers are an excellent nutrient whereas raw sewage sludge carries a large volume of microorganisms, as evidenced by the results of microbiological tests (see: next sub-chapter). Sewage sludge enables the production of a relatively
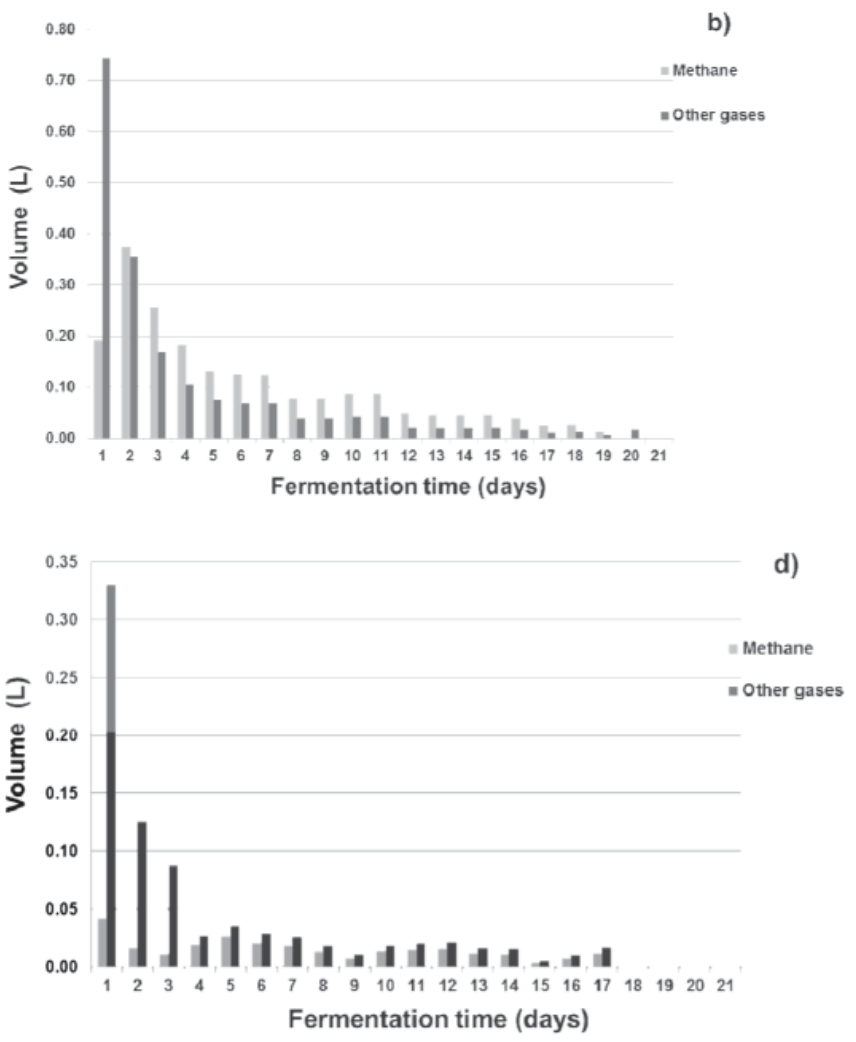

Fig. 3. Daily biogas production from samples: a) WF/inoculum, b) SS/inoculum, c) WF_SS/inoculum, and d) inoculum. 
Table 4. Cumulative biogas and methane yields.

\begin{tabular}{|c|c|c|c|c|c|}
\hline \multirow{2}{*}{ Sample } & \multicolumn{2}{|c|}{ Biogas } & \multicolumn{2}{c|}{ Methane } & \multirow{2}{*}{$\begin{array}{c}\mathrm{CH}_{4} \\
(\%)\end{array}$} \\
\cline { 2 - 6 } & $\left(\mathrm{m}^{3} \mathrm{Mg}^{-1} \mathrm{TS}\right)$ & $\left(\mathrm{m}^{3} \mathrm{Mg}^{-1} \mathrm{VS}\right)$ & $\left(\mathrm{m}^{3} \mathrm{Mg}^{-1} \mathrm{TS}\right)$ & $\left.4 \mathrm{~m}^{3} \mathrm{Mg}^{-1} \mathrm{VS}\right)$ & 50.3 \\
\hline WF/inoculum & 967.8 & 980.1 & 486.2 & 177.9 & 51.0 \\
\hline SS/inoculum & 320.4 & 349.1 & 163.3 & 387.5 & 58.0 \\
\hline WF_SS/inoculum & 638.1 & 667.9 & 370.2 & & 592.6 \\
\hline
\end{tabular}

calorific biogas and, in this respect, it has a favorable effect on the anaerobic co-digestion process [17].

As regards production output, for the WF SS sample $667.9 \mathrm{~m}^{3} \mathrm{Mg}^{-1} \mathrm{VS}$ of biogas and $387.5 \mathrm{~m}^{3} \mathrm{Mg}^{-1} \mathrm{VS}$ ofmethane was obtained in terms of volatile solids. The result for the co-digestion of WF_SS was a little worse in comparison with that for WF. The differences in biogas production for the samples referred to in this paper were primarily connected with the substrates composition with respect to biodegradability; more specifically - to the content of readily degradable organic compounds, which is certainly higher for the test WF. Moreover, the influence on the result was the low $\mathrm{C} / \mathrm{N}$ of sewage sludge. It is worth mentioning also that the raw SS contains pesticides, polychlorinated heavy metals, dioxins (PCB), polycyclic aromatic hydrocarbons (PAH), and other substances, which potentially inhibit the activity of bacterial flora [17, 28]. Heavy metals (especially at high concentrations) have a toxic effect in anaerobic digestion because they disturb the action and structure of the enzymes that catalyze numerous anaerobic reactions; this, consequently, leads to lower yields of methane production $[22,28]$. However, in the case of the results presented in this paper, the effect is only hypothetical.

\section{Microbiological and Biochemical Analysis}

In a microbiological analysis, the highest number of heterotrophic bacteria (Eubacteria) were found in the raw sewage sludge (SS) and, according to the analysis of means for the respective groups, the value was just slightly higher for WF_SS. The high number of microorganisms in the raw sewage sludge is probably due to the fact that the non- processed sludge is rich in microorganisms originating from different environments [33]. The lowest number of bacteria was typical of the digested sewage sludge in the form of inoculum (Fig. 4a).

The number of bacteria in the digestion process was $10^{3} \mathrm{cfu}^{-\mathrm{g}^{-1}} \mathrm{TS}$ of digestion mixtures regardless of the test sample type (Fig. 4a). After continuing the process for three days (time point II), the number of bacteria was found to be lower in all the starting materials except $\mathrm{SS}$. At the following time points (till time point $\mathrm{V}$ - Day 13 of the process) the value of the parameter varied depending on the type of digested waste, after which on time points VI (Day 17) and VII (Day 21) fewer bacteria were found to have multiplied as the AD substrate was slowly becoming depleted. A statistical analysis indicates that, with the exception of time point II of the study, the type of digested organic waste did not have a statistically significant effect on microbial growth and development. Similar relationships were recorded in the test, which was carried out in the presence of highly processed food waste [17].

Dehydrogenases are the essential enzymes used in the analyses of the biological activity of culture media. They are regarded as an indicator of the breathing activity of organisms [34]. Their presence in a medium indicates the presence of active microorganisms. Dehydrogenase activity depends on the microbial count and microbial species, the physico-chemical properties of culture media, catalytic performance, and the number of compounds taking part in enzymatic reactions [35]. When analyzing changes of the level of dehydrogenase activity in the test materials (Fig. 4b), it was found that the highest enzymatic activity during the test was observed for the WF_SS test
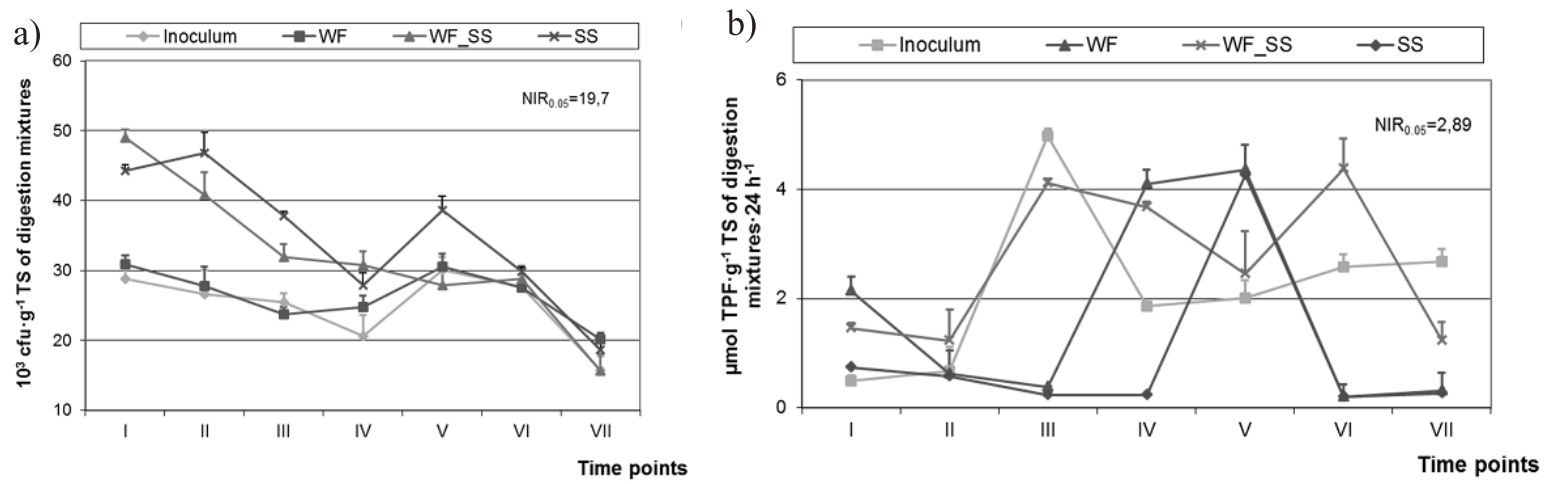

Fig. 4. a) Changes in the number of anaerobic bacteria and b) changes of dehydrogenase activity during anaerobic digestion. 


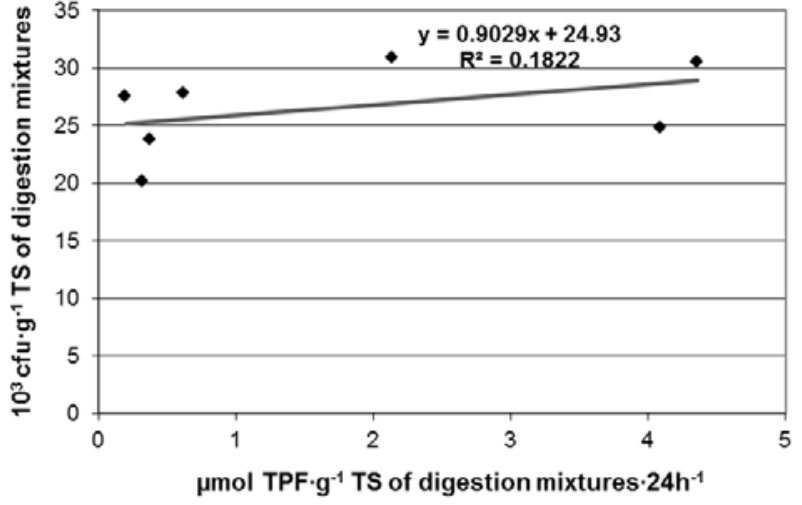

Fig. 5. Correlation between the number of anaerobic bacteria and dehydrogenase activity in digested WF/inoculum sample.

sample (comparable to the inoculum), and the lowest for the raw sewage sludge SS. The conclusion concerning the bacterial count and activity in the sewage sludge was formulated in the previous paper by the same authors [17]. The observed high level of metabolic activity in the microorganisms for the mixture of wafers and sewage sludge may have resulted from the combination of the two materials (sewage sludge and wafers) having quite different chemical compositions. In that system, the numerous bacteria that were present in the sewage sludge were activated by the nutrient in the form of wafers. The result was a high $(58 \%)$ share of methane in the biogas obtained from the WF_SS test sample, although the AD process yield for that starting material is positively lower (Fig. 3c), Table 4) in comparison with that for the WF test sample (Fig. 3a). The dehydrogenase activities were observed to vary during the experiment, depending on the waste type (Fig. 4b). At time point V, the dehydrogenase activity decreased for the WF and SS test samples and increased for WF_SS at the time, and the tendency continued into time point VI.

A straight-line regression was used to show a relationship between the number of true bacteria (Fig. 4a) and the level of dehydrogenase activity (Fig. 4b). The analysis showed that there is virtually no relationship between the parameters in question for most experimental objects, except for the WF test sample, for which positive Pearson linear correlation (Fig. 5) was recorded. The fact confirms that waste wafers with filling are a suitable bacterial medium having a high methanogenic potential.

\section{Conclusions}

In the present paper, the disposal of waste wafers from confectionery production by anaerobic digestion was proposed. The process stability and biogas yield were investigated for the substrate alone and in combination with raw sewage sludge as the co-substrate.

The highest yields of biogas and methane were obtained for waste wafers $\left(980.1 \mathrm{~m}^{3} \mathrm{Mg} \mathrm{VS}^{-1}\right.$ and
$492.6 \mathrm{~m}^{3} \mathrm{Mg} \mathrm{VS}^{-1}$, respectively) and the lowest for raw sewage sludge (349.1 $\mathrm{m}^{3} \mathrm{Mg}^{-1} \mathrm{VS}$ and $177.9 \mathrm{~m}^{3} \mathrm{Mg}^{-1} \mathrm{VS}$, respectively). The cumulative biogas yield $\left(667.9 \mathrm{~m}^{3} \mathrm{Mg}\right.$ $\left.\mathrm{VS}^{-1}\right)$, including methane $\left(387.5 \mathrm{~m}^{3} \mathrm{Mg} \mathrm{VS}^{-1}\right)$ for wafers with sewage sludge (WF_SS) was lower in comparison with WF alone, which is mainly related to the different chemical compositions of both substrates. However, the combination of the two kinds of waste is beneficial due to the relatively high number of anaerobic bacteria as well as dehydrogenase activity during the anaerobic digestion, which leads to a significant share $(58 \%)$ of methane in the biogas. In future research works involving waste wafers and sewage sludge it is recommended to carry out experiments with continuous co-digestion (which more resembles the functioning of biogas plants) under steady state conditions in order to assess the effectiveness of a process and to identify any possible barriers (inhibition factors).

Before the implementation of these substrate systems (WF_SS) in a biogas plant, it is necessary to consider the following problem: would it be easier for the confectionery unit to invest in the construction of a biogas plant to treat their waste wafers and produce biogas (i) or would it be better to transfer their waste wafers to the anaerobic digestion unit in the municipal wastewater treatment plant to co-digest with SS and increase the biogas output of the plant (ii)? It seems that, for logistical reasons, it is more cost-effective to supply the wafers to the existing biogas plants operated at the municipal wastewater treatment plants than to transport sewage sludge or build new facilities. However, the question remains open for further discussion.

\section{Acknowledgements}

This work was supported by the companies BiolabEnergy A\&P and Badania i Wdrożenia QUARK Sp. z o.o. [Ltd.], Poznan, Poland. Moreover, the author is grateful to Dr. Agnieszka Wolna-Maruwka for her assistance in performing the microbiological tests.

\section{References}

1. MATA-ALVAREZ J., MACÉ S., LLABRÉS P. Anaerobic digestion of organic solid wastes. An overview of research achievements and perspectives. Bioresour. Technol. 74, 3, 2000.

2. ZHANG C., SU H., BAEYENS J., TAN T. Reviewing the anaerobic digestion of food waste for biogas production. Renew. Sust. Energ. Rev. 38, 383, 2014.

3. APPELS L., ASSCHE A.V., WILLEMS K., DEGRÈVE J., IMPE J.V., DEWIL R. Peracetic acid oxidation as an alternative pre-treatment for the anaerobic digestion of waste activated sludge. Bioresour. Technol. 102, 4124, 2011.

4. KNITTEL K., BOETIUS A. Anaerobic oxidation of methane: progress with an unknown process. Annu. Rev. Microbiol. 63, 311, 2009.

5. SUWANNARAT J., RITCHIE R.J. Anaerobic digestion of food waste using yeast. Waste. Manage. 42, 61, 2015. 
6. ZESHAN M.J., YOUSAF S., HAIDER M.R., MALIK R.N. High-solids anaerobic co-digestion of food waste and rice husk at different organic loading rates. Int. Biodeter. Biodegr. 102, 149, 2015.

7. RAZAVIARANI V., BUCHANAN I.D., MALIK S., KATALAMBULA H. Pilot-scale anaerobic co-digestion of municipal wastewater sludge with restaurant grease trap waste. J. Environ. Manage. 123, 26, 2013.

8. MONTANÉS, R., PÉREZ M., SOLERA R. Anaerobic mesophilic co-digestion of sewage sludge and sugar beet pulp lixiviation in batch reactors: Effect of $\mathrm{pH}$ control. Chem. Eng. J. 255, 492, 2014.

9. FANG C., BOE K., ANGELIDAKI I. Anaerobic codigestion of desugared molasses with cow manure; focusing on sodium and potassium inhibition. Bioresour. Technol. 102, 1005, 2011

10. PILARSKA A. A., PILARSKI K., WITASZEK K., WALISZEWSKA H., ZBOROWSKA M., WALISZEWSKA B., KOLASIŃSKI M., SZWARC-RZEPKA K. Treatment of dairy waste by anaerobic digestion with sewage sludge. Ecol. Chem. Eng. S. 23 (1), 99, 2016.

11. SILVESTRE G., ILLA J., FERNÁNDEZ B., BONMATÍ A. Thermophilic anaerobic co-digestion of sewage sludge with grease waste: Effect of long chain fatty acids in the methane yield and its dewatering properties. Appl. Energy. 117, 87, 2014.

12. NEVES L., OLIVEIRA R., ALVES M.M. Anaerobic codigestion of coffee waste and sewage sludge. Waste. Manage. 26, 176, 2006.

13. DI MARIA F., SORDI A., CIRULlI G., MICALE C. Amount of energy recoverable from an existing sludge digester with the co-digestion with fruit and vegetable waste at reduced retention time. Appl. Energ. 150, 9, 2015.

14. PILARSKA A.A., PILARSKI K., RYNIECKI A., TOMASZYK K., DACH J., MARUWKA-WOLNA A. Utilization of vegetable dumplings waste from industrial production by anaerobic digestion. Int. Agrophys. 31 (1), 93, 2017.

15. LAFITTE-TROUQUÉ S., FORSTER C.F. Dual anaerobic co-digestion of sewage sludge and confectionery waste. Bioresour Technol. 71, 77, 2000.

16. RUSÍN J., KAŠÁKOVÁ K., CHAMRÁDOVÁ K. Anaerobic digestion of waste wafer material from the confectionery production. Energy. 85, 194, 2015.

17. PILARSKA A.A., PILARSKI K., WOLNA-MARUWKA A., TOMASZYK K. Anaerobic co-digestion of highly processed food waste with sewage sludge. Physicochemical and microbiological evaluation of the process. Chem. Ind. 195 (11), 2216, 2016.

18. PILARSKA A., PILARSKI K., DACH J., WITASZEK K. Impact of organic additives on biogas efficiency of sewage sludge. Agric. Eng. 3, 139, 2014.

19. BOROWSKI S. Co-digestion of the hydromechanically separated organic fraction of municipal solid waste with sewage sludge. J. Environ. Manage. 147, 87, 2015.

20. NARTKER S., AMMERMANA M., AURANDT J., STOGSDIL M., HAYDEN, O., ANTLE C. Increasing biogas production from sewage sludge anaerobic co-digestion process by adding crude glycerol from biodiesel industry. Waste. Manage. 34, 2567, 2014.

21. DONG B., LIU X., DAI L. Changes of heavy metal speciation during high-solid anaerobic digestion of sewage sludge. Bioresour. Technol. 131, 152, 2013.
22. MUDHOO A., KUMAR S. Effects of heavy metals as stress factors on anaerobic digestion processes and biogas production from biomass. Int. J. Environ. Sci. Technol. 10, 1383, 2013.

23. SOSNOWSKI P., KLEPACZ-SUELTA A., KACZOREK K., LEDAKOWICZ S. Kinetics investigations of methane co-fermentation of sewage sludge and organic fraction of municipal solid wastes. Bioresour. Technol. 99, 5731, 2008.

24. NORM VDI 4630. Vergärung organischer Stoffe Substratcharakterisierung, Probenahme, Stoffdatenerhebung, Gärversuche [Fermentation of organic materials characterization of the substrate, sampling, collection of material data, fermentation tests]. Düsseldorf: Verein Deutscher Ingenieure - German Engineers Club, 2006.

25. NORM DIN 38 414-S8. Bestimmung des Faulverhaltens (S8) Schlamm und Sedimente [Fermentation of organic materials - Characterisation of the substrate, sampling, collection of material data, fermentation tests]. Deutsches Institut für Normung, 1985.

26. PILARSKA A.A., PILARSKI K., WALISZEWSKA B., ZBOROWSKA M., WITASZEK K., WALISZEWSKA H., KOLASIŃSKI M., SZWARC-RZEPKA K. Evaluation of bio-methane yields for high-energy organic waste and sewage sludge: a pilot-scale study for a wastewater treatment plant. Environ. Eng. Manage. J. accepted

27. THALMANN A., Zur methodik der bestimmung der dehydrogenase aktivität in boden mittels triphenyltetrazoliumchlorid (TTC) [Methods of dehydrogenase activity determination with triphenyltetrazoliumchlorid (TTC)]. Landwirtsch. Forsch. 21, 249, 1968.

28. CHEN Y., CHENG J.J., CREAMER K.S. Inhibition of anaerobic digestion process: A review. Bioresour. Technol. 99, 4044, 2008.

29. WAN C., ZHOU Q., FU G., LI Y. Semi-continuous anaerobic co-digestion of thickened waste activated sludge and fat, oil and grease. Waste. Manage. 31, 1752, 2011.

30. SILVESTRE G., RODRÍGUEZ-ABALDE A., FERNÁNDEZ B., FLOTATS X., BONMATÍ A. Biomass adaptation over anaerobic co-digestion of sewage sludge and trapped grease waste. Bioresour. Technol. 102, 6830, 2011.

31. ZHU Z., HSUEH M., HE Q. Enhancing biomethanation of municipal waste sludge with grease trap waste as a cosubstrate. Renew Energy. 36, 1802, 2011.

32. DEUBLEIN D., STEINHAUSER A. Biogas from waste and renewable resources. 2nd Ed., WILEY-VCH Verlag GmbH \& Co KGaA, Weinheim, 151, 2011.

33. POPOVAL T.P., ZAHARINOV B., MARINOVAGARVANSKA S.M., BAYKOV B. Microbiological evaluation of sewage sludge in terms of possibilities of application in soil as a fertilizer. Int. J. Curr. Microbiol. App. Sci. 3 (9), 184, 2014.

34. KUMAR S., ChAUDHURI S., MAITI S.K. Soil dehydrogenase enzyme activity in natural and mine soil - A review. Middle East J. Sci. Res. 13 (7), 898, 2013.

35. WŁODARCZYK T., STĘPNIEWSKI W., BRZEZIŃSKA M. Dehydrogenase activity, redox potential, and emissions of carbon dioxide and nitrous oxide from Cambisols under flooding conditions. Biol. Fert. Soils. 36, 200, 2002 